\title{
Penggunaan Ekstrak Metanol Bawang Putih (Allium sativum) Sebagai Feed Additive Terhadap Kualitas Karkas Ayam Broiler
}

\section{The Use of Garlic Methanol Extract as Feed Additive on Carcass Quality of Broiler Chickens}

\author{
U. Haroen* dan A. Budiansyah \\ Program Studi Peternakan, Fakultas Peternakan, Universitas Jambi, Jambi-36361 \\ *E-mail: ucop-haroen@unja.ac.id
}

(Diterima: 08 Januari 2019; Disetujui: 18 Maret 2019)

\begin{abstract}
ABSTRAK
Penelitian ini bertujuan untuk melihat sejauh mana efek pemberian ekstrak metanol (MeOH) bawang putih (Allium sativum) sebagai feed additive terhadap konsumsi ransum dan kualitas dari karkas ayam broiler (bobot karkas, persentase bobot karkas, kolesterol karkas, dan bobot lemak abdomen) dan konsumsi air minum ayam broiler. Materi yang dipergunakan dalam penelitian ini adalah ayam broiler umur satu hari sebanyak 200 ekor galur Lohman. Penelitian di desain menggunakan Rancangan Acak Lengkap terdiri 5 perlakuan dan 4 ulangan setiap ulangan terdiri dari 10 ekor ayam. Perlakuan terdiri dari P0 = Air minum tanpa penambahan ekstrak metanol bawang putih (kontrol); P1 = Air minum dengan penambahan ekstrak metanol bawang putih 250 ppm; P2 = Air minum dengan penambahan ekstrak metanol bawang putih 500 ppm; P3= Air minum dengan penambahan ekstrak metanol bawang putih 750 ppm; P4= Air minum dengan penambahan ekstrak metanol bawang putih 1000 ppm.Peubah yang diamati antara lain konsumsi ransum, bobot potong, dan kualitas karkas (bobot karkas, persentase bobot karkas, kolesterol karkas dan bobot lemak abdomen) dan konsumsi air minum. Hasil penelitian terhadap penggunaan ekstrak metanol bawang putih nyata $(\mathrm{P}<0,05)$ meningkatkan bobot potong dan bobot karkas serta menurunkan kandungan kolesterol karkas dan bobot lemak abdomen, tetapi tidak mempengaruhi konsumsi air minum dan persentase karkas. Dari hasil penelitian ini dapat disimpulkan bahwa penggunaan ekstrak metanol bawang putih (Allium sativum) dapat digunakan sampai taraf 1000 ppm dengan meningkatkan bobot potong, bobot karkas dan konsumsi ransum, serta menurunkan kolesterol karkas dan bobot lemak abdomen.
\end{abstract}

Kata kunci: broiler, ekstrak bawang putih, kualitas karkas, metanol

\section{ABSTRACT}

This study aims of the research were to know the effect of giving garlic (Allium sativum) that was extracted with methanol as a feed additive in broiler ration on feed intake and carcass quality of broiler (carcass weight, carcass weight percentage, carcass cholesterol, and abdominal fat weight) and drinking water consumption. The material at the research was used two hundred unsexed 1d-old chicks (Lohman strain) at broiler chickens. Designed of the research was using Completely Randomized Design consisting of five treatments and four replication were consist of 10 birds. Treatment groups were as follows P0= drinking water without addition of garlic methanol extract (control): $P 1=$ drinking water with addition of garlic methanol extract 250 ppm: P2 = drinking water with addition of garlic methanol extract 500 ppm: $P 3=$ drinking water with addition of garlic methanol extract $750 \mathrm{ppm}:$ P4 = drinking water with addition of garlic methanol extract 1000 ppm. The variables observed that were included feed intake, slaughter weight and carcass quality (carcass weight, carcass weight percentage, carcass cholesterol, and abdominal fat weight) and drinking water consumption. The results at the study that the used of garlic that was with methanol had a significant effect $(P<0.05)$ increased feed intake, the slaughter weight and decreasing carcass cholesterol and abdominal fat weight, but not affecting on drinking water consumption and carcass weight percentage. The research concluded that the used of garlic (Allium sativum) that was extracted with methanol could be used up to 1000 ppm by increasing slaughter weight, carcass weight, and feed intake and reducing carcass cholesterol and abdominal fat weight. 
Vol. 21 (2): 109-121

Keywords: broiler, carcass quality, garlic (Allium sativum) extract, methanol

\section{PENDAHULUAN}

Growth promoter berbasis antibiotik sintetis secara umum telah banyak digunakan sebagai feed additive dalam pakan ternak unggas, karena feed additive ini dapat membantu tubuh ternak tumbuh lebih cepat dan dapat mencerna makanan lebih efisien dan dapat berfungsi untuk meningkatkan daya tahan tubuh ternak menjadi lebih sehat (Sojoudi et al., 2012). Beberapa feed additive yang berupa antibiotik sentetis yang umum digunakan dalam pakan ternak unggas antara lain avilamycin, neomysin, salinomysin, virginiamycin dadoxycyclin (Kumar et al., 2010).

Penggunaan feed additive dengan tujuan sebagai pemacu pertumbuhan berbasis antibiotik sintetis saat ini telah mendapat kritik yang serius dan keprihatinan global, karena dapat memberi efek negatif yang mengkonsumsi produk ternak tersebut, antara lain dapat menimbulkan resistensi mikroba, dan berpotensi membahayakan kesehatan manusia (Rahmatnejad et al., 2009). Untuk mengatasi masalah ini perlu adanya upaya yang mengarah pada pemakaian feed additive alami sebagai bahan pakan alternatif yang berasal dari alami agar dapat mengatasi masalah tersebut diatas (Manesh, 2012).

Saat ini sudah banyak para peneliti atau ahli gizi unggas menggunakan growth promoter atau pemacu pertumbuhan menggunakan bahan pakan alami seperti probiotik, prebiotik atau kombinasi probiotik dan prebiotik maupun tanaman obat-obatan sebagai feed aditive alami dalam pakan ternak unggas salah satunya adalah bawang putih (Allium sativum) Khan et al. (2010; 2011a). Bawang putih (Allium sativum) telah dikenal dalam pengobatan tradisional selama ribuan tahun dalam sejarah Yunani dan Mesir (Horton et al., 1991). Bawang putih paling dikenal sebagai rempah-rempah atau obat herbal untuk pengobatan dan pencegahan berbagai penyakit (Adibmoradi et al., 2006).

Bawang putih mengandung 33 senyawa aktif yang mengandung sulfur, beberapa enzim, 17 asam amino dan mineral termasuk selenium (Newall et al., 1996). Metabolik sekunder yang dominan dalam bawang putih adalah allicin, ajoene, diakilpolysulphides, s-allylcysteine, diallydisulphide, s-methylcysteine sulphoxide dan s-allylcysteine sulphoxide, yang akan bertanggung jawab atas sifat terapeutik bawang putih (Canogullari et al., 2010).

Akhir-akhir ini, penelitian penggunaan bawang putih dalam ransum terhadap pertumbuhan ternak unggas telah banyak dilaporkan. Menurut Mansoub (2011), pemberian tepung bawang putih $1 \mathrm{~g} / \mathrm{kg}$ dalam ransum basal dapat meningkatkan rasio konversi pakan (FCR) dan berat badan (BW) ayam broiler. Aji et al. (2011) menyatakan pemakaian $100 \mathrm{mg}$ bawang putih dalam pakan ternak unggas terjadi peningkatan berat badan ayam broiler pada umur 7, 14 dan 21 hari, meskipun konsumsi pakan dan bobot karkas tidak nyata. Selanjutnya Kumar et al. (2010) melaporkan bahwa ransum yang diberi suplemen bawang putih sebanyak $250 \mathrm{ppm}$ nyata meningkatkan berat badan ayam broiler sampai umur 42 hari. Pourali et al. (2010) mengatakan penambahan tepung bawang putih pada pakan ternak unggas mengakibatkan konsumsi ransum, pertambahan berat badan, konversi ransum meningkat dan sekaligus dapat meningkatkan daya tahan tubuh ayam broiler.

Mahmood et al. (2009) melaporkan pemberian ransum yang mengandung $0,5 \%$ bawang putih dapat meningkatkan konversi ransum dan berat badan ayam dan tidak berdampak negatif terhadap perkembangan jantung, rempela, hati, limpa dan pankreas. Javed et al. (2009) melaporkan pemberian ekstrak bawang putih $10 \mathrm{ml} /$ liter air minum mengakibatkan konsumsi pakan, dan kualitas karkas ( persentase karkas, pertambahan berat 


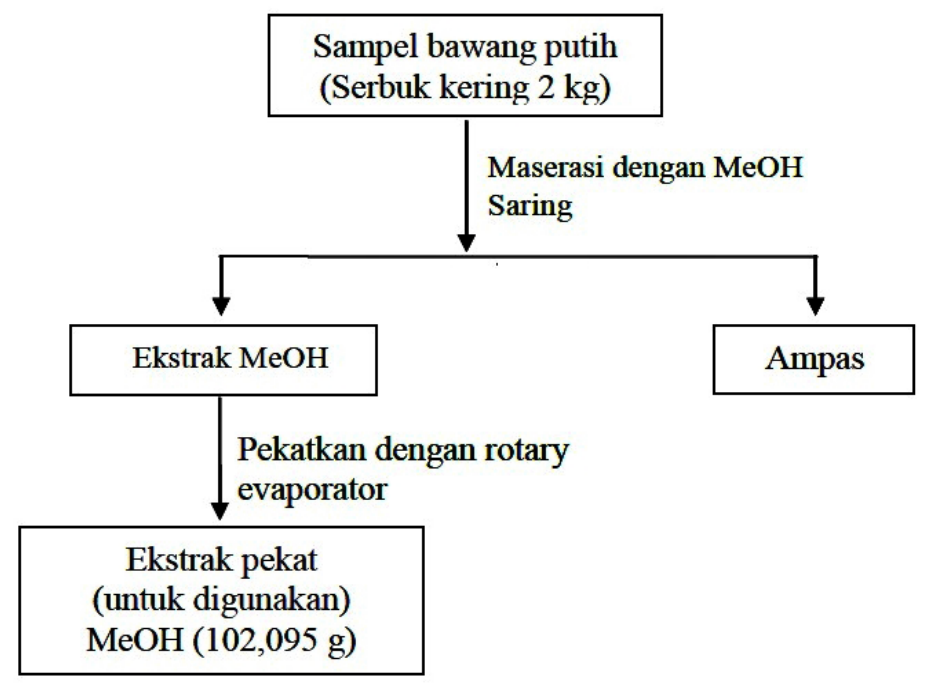

Gambar 1. Alur kerja ekstraksi bawang putih (Perez et al., 2010)

badan harian dan bobot potong) meningkat serta menurunkan konversi ransum pada ayam broiler umur 35 hari. Ramakrishna et al. (2003) mengatakan bahwa suplemen bawang putih (Allium sativum) dapat meningkatkan aktivitas enzim pancreas, sehingga pencernaan bahan pakan lebih baik dan sekaligus dapat meningkatkan penyerapan zat-zat makanan dalam saluran pencernaan.

Rahmini et al. (2011) menyatakan bahwa senyawa aktif yang terdapat dalam bawang putih (Allium sativum) terutama allicin, ajoene memiliki kemampuan sebagai antibakteri, anti alergi, anti tumor dan anti inflamasi. Hanieh et al. (2010) melaporkan bahwa pemberian tepung bawang putih dalam ransum taraf $10 \mathrm{~g} / \mathrm{kg}$ dapat meningkatkan daya tahan tubuh ayam White Leghorn. Selanjutnya Dorhoi et al. (2006) mengatakan pemberian suplemen ekstrak bawang putih dalam air minum sebanyak $50 \mu \mathrm{g} / \mathrm{ml}$ dapat meningkatkan daya tahan tubuh ayam petelur. Rahimi et al. (2011) mengatakan bahwa penggunaan $0,1 \%$ bawang putih dalam ransum ayam pedaging meningkatkan respon antibody, peningkatan berat limpa dan hipersensitivitas respon basofilik kooperatif. Peningkatan berat limpa dan thymus disebabkan dengan peningkatan proliferasi limfosit dan peningkatan produksi leukosit. Hanieh et al. (2010) menyatakan bahwa efek immuno modulasi dari bawang putih disebabkan keberadaan dan kemampuan fungsi antioksidan dari bawang putih.

Berdasarkan uraian diatas maka dilakukan penelitian tentang "Penggunaan Ekstrak Bawang Putih (Allium Sativum) Sebagai Feed Additive Terhadap Kualitas KarkasAyam Broiler".

\section{METODE}

Materi yang digunakan pada penelitian iniadalah ayam broiler umur satu hari (DOC) sebanyak 200 ekor tanpa pemisahan jantan dan betina (unsex) strain Lohman. Peralatan yang digunakan adalah kandang unit berjumlah 20 unit terbuat dari kawat, setiap unit kandang terdiri dari 10 ekor anak ayam, lampu 40 watt, tempat pakan, tempat air minum, pisau potong (karter), terpal, talenan, plastik, ember, panci, pengukur kelembaban dan suhu kandang menggunakanhygrometer dan thermometer dinding. Timbangan merk "Ohous" kapasitas 2610 g dan "Sartorius" kapasitas 1200 g dengan sistem digital. Ekstrak metanol bawang putih, bahan pakan dan bahan-bahan 
Tabel 1. Kandungan zat-zat makanan bahan pakan ransum penelitian (nutrient composition of feeds Inggredient in the experimental rations)

\begin{tabular}{|c|c|c|c|c|c|c|c|}
\hline No & $\begin{array}{c}\text { Bahan Pakan } \\
\text { (Inggredient } \% \text { as } \\
\text { fed-basis) }\end{array}$ & $\begin{array}{c}\text { Energi } \\
\text { metabolisme } \\
(\text { Kkal } / \mathrm{kg}) \\
\text { (Metabolizable } \\
\text { energy) } \\
(\mathrm{Kcal} / \mathrm{kg})\end{array}$ & $\begin{array}{c}\text { Protein } \\
\text { kasar }(\text { Crude } \\
\text { protein }) \%\end{array}$ & $\begin{array}{l}\text { Lemak } \\
\text { kasar } \\
(\text { Ether } \\
\text { extract }) \%\end{array}$ & $\begin{array}{l}\text { Serat kasar } \\
\text { (Crude } \\
\text { fiber) } \%\end{array}$ & $\begin{array}{c}\text { Kalsium } \\
\text { (Calcium) } \\
\%\end{array}$ & $\begin{array}{c}\text { Posfor } \\
\text { (Phosphorus) } \\
\%\end{array}$ \\
\hline 1 & $\begin{array}{l}\text { Jagung kuning } \\
\text { (Yellow corn }) \%\end{array}$ & 3370 & 8,9 & 2,29 & 1,5 & 0,4 & 0,2 \\
\hline 2 & $\begin{array}{c}\text { BungkilKedele } \\
\text { (Soybean meal) \% }\end{array}$ & 2671 & 47,5 & 2,3 & 1,6 & 0,7 & 0,8 \\
\hline 3 & $\begin{array}{l}\text { Tepung Ikan } \\
\text { (Fish meal) \% }\end{array}$ & 2393 & 48,3 & 8,5 & 3,5 & 9,2 & 4,6 \\
\hline 4 & $\begin{array}{l}\text { Bungkil Kelapa } \\
\text { (Coconut cake) \% }\end{array}$ & 2629 & 21,2 & 10,5 & 12,2 & 0,4 & 0,7 \\
\hline 5 & $\begin{array}{c}\text { Poles } \\
\text { (Rice polished) } \%\end{array}$ & 2530 & 8,7 & 3,1 & 1,6 & 0,5 & 0,6 \\
\hline 6 & $\begin{array}{l}\text { Minyak jagung } \\
\text { (Corn oil) } \%\end{array}$ & 8600 & 0 & 100 & 0 & 0 & 0 \\
\hline
\end{tabular}

Keterangan: NRC (1994)

Tabel 2. Susunan bahan pakan dalam ransum penelitian periode starter dan periode finisher (The composition of feeds inggredient in experimental rations periode starter and periods finisher)

\begin{tabular}{clcc}
\hline No & $\begin{array}{l}\text { Bahan Pakan } \\
\text { (Inggredient \% ) }\end{array}$ & $\begin{array}{c}\text { Periode starter (\%) } \\
\text { (starter period \%) }\end{array}$ & $\begin{array}{c}\text { Periode finisher (\%) } \\
\text { (finisher period \%) }\end{array}$ \\
\hline 1 & Jagung kuning (Yellow corn) \% & 45 & 44 \\
2 & Bungkil Kedele (Soybean meal) \% & 24 & 22 \\
3 & Tepung Ikan (Fish meal) \% & 10 & 8 \\
4 & Bungkil Kelapa (Coconut cake) \% & 9 & 9 \\
5 & Poles (Rice polished) \% & 8 & 12 \\
6 & Minyak jagung (Corn oil) \% & 2,50 & 3,5 \\
7 & Premix & 0,2 & 0,5 \\
8 & CaCO & 0,8 & 0,5 \\
9 & DL-metionin (DL- methionine) \% & 0,25 & 0,25 \\
10 & L-Lisisn (L- lysine) \% & 0,25 & 0,25 \\
\hline & Jumlah (Total) \% & 100 & 100 \\
\hline
\end{tabular}

penyusun ransum lainnya adalah terdiri dari jagung kuning, bungkil kedelai, tepung ikan, bungkil kelapa serta bahan-bahan lain seperti tepung tulang $(\mathrm{CaCO} 3)$, DL-metionin, L-lisin, dan topmix buatan Medion.

Rancangan yang digunakan dalam penelitian ini adalah Rancangan Acak Lengkap
5 perlakuan. Perlakuan yang diberikan sebagai berikut : $\mathrm{P} 0=$ Air minum tanpa penambahan ekstrak metanol bawang putih (kontrol), P1 $=$ Air minumdengan penambahan ekstrak metanol bawang putih $250 \mathrm{ppm}, \mathrm{P} 2=$ Air minum dengan penambahan ekstrak metanol bawang putih $500 \mathrm{ppm}, \mathrm{P} 3=$ Air minum 
Tabel 3. Kandungan zat-zat makanan ransum penelitian periode starter dan periode finisher (Nutrient composition of feeds Inggredient in the experimental rations starter period and finisher period)

\begin{tabular}{lcccccccc}
\hline $\begin{array}{l}\text { Periode } \\
\text { (Period) }\end{array}$ & $\begin{array}{c}\mathrm{BK}^{*} \\
(\mathbf{\%})\end{array}$ & $\begin{array}{c}\text { Abu* } \\
(\%)\end{array}$ & $\begin{array}{c}\mathrm{PK}^{*} \\
(\%)\end{array}$ & $\begin{array}{c}\mathrm{LK}^{*} \\
(\mathbf{\%})\end{array}$ & $\begin{array}{c}\mathrm{SK}^{*} \\
(\%)\end{array}$ & $\begin{array}{c}\mathrm{Ca}^{* *} \\
(\%)\end{array}$ & $\begin{array}{c}\mathrm{P}^{* *} \\
(\%)\end{array}$ & $\begin{array}{c}\mathrm{EM}^{* *} \\
(\text { Kkalori } / \mathrm{kg})\end{array}$ \\
\hline Starter & 89,04 & 9,22 & 23,79 & 5,60 & 4,15 & 0,75 & 0,60 & 3005,45 \\
Finisher & 87,99 & 8,06 & 21,98 & 4,65 & 4,45 & 0,17 & 0,36 & 2069,70 \\
\hline
\end{tabular}

Keterangan: * Hasil Analisis Laboratorium Nutrisi Makanan Ternak Fakultas Peternakan Universitas Jambi (2018)

** Hasil Perhitungan Tabel 1 dan Tabel 2

dengan penambahan ekstrak metanol bawang putih 750 ppm, dan $\mathrm{P} 4=$ Air minumdengan penambahan ekstrak metanol bawang putihn $1000 \mathrm{ppm}$.

Masing-masing perlakuan diulang 4 kali sehingga didapat 20 unit percobaan dan setiap ulangan terdapat 10 ekor ayam. Data yang diperoleh dianalis ragam yang digunakan untuk menguji pengaruh perlakuan sesuai rancangan yang digunakan yaitu Rancangan Acak Lengkap.

\section{Ekstraksi metanol bawang putih}

Bawang putih dibeli dari pedagang rempah-rempah yang berada di kota Jambi, Bawang putih yang digunakan adalah bawang putih lokal yang biasa digunakan untuk bumbu masak yang ada di pasar kota Jambi (Allium sativum). Bawang putih dikeringkan menggunakan oven pada suhu $55{ }^{\circ} \mathrm{C}$ selama 3-4 hari sampai kadar air 10$15 \%$, kemudian digiling dijadikan tepung dengan menggunakan hamer mill. Bahan kimia yang digunakan berupa pelarut organik yaitu Metanol $(\mathrm{MeOH})$ teknis yang didistilasi dan aquadest. Untuk lebih jelasnya proses ekstraksi bawang putih dapat dilihar pada Gambar 1.

\section{Penyusunan Ransum}

Ransum penelitian disusun sesuai kebutuhan ayam periode starter dan periode finisher mengacu pada Tabel NRC (1994), terdiri dari jagung kuning, tepung ikan, bungkil kedelai, bungkil kelapa, poles serta bahan-bahan lain seperti minyak sayur, premix, $\mathrm{CaCO}_{3}$, methionin, dan lysine.
Komposisi nutrien dan komposisi bahan pakan penyusun ransum serta komposisi nutrien ransum periode starter dan periode finisher dapat dilihat disajikan pada Tabel 1, 2,3 .

\section{HASIL DAN PEMBAHASAN}

Analisis ragam menunjukkan penggunaan ekstrak metanol bawang putih dalam air minum selama penelitian hingga taraf $1000 \mathrm{ppm}$ tidak memberikan pengaruh nyata $(\mathrm{P}>0,05)$ terhadap konsumsi air minum ayam broiler per ekor per hari (Tabel 4).

Rataan konsumsi air minum ayam broiler selama penelitian ini berkisar antara 145,09-156,76 $\mathrm{ml} /$ ekor/hari dan tidak terdapat perbedaan nyata antara perlakuan penggunaan ekstrak metanol bawang putih dengan perlakuan tanpa penggunaan ekstrak metanol bawang putih. Rataan konsumsi air minum ayam pada penelitian ini hampir sama dengan hasil penelitian Nurhayati, (2008) penggunaan jus mengkudu menghasilkan rataan konsumsi air minum berkisar antara 111,13-123,06 ml/ekor/hari. Selanjutnya hasil penelitian Herman, (2005) pemberian air minum mengandung $1,55 \%$ larutan rimpang kunyit konsumsi air minum ayam broiler rata-rata 133,28 $\mathrm{ml} / \mathrm{ekor} /$ hari. Sedangkan hasil penelitian dengan penggunaan probiotik dalam air minum ayam broiler konsumsi air minum rata-rata 174,91-184,00 ml/ekor/hari dan konsumsi air minum dengan pemberian air rebusan kunyit $0,01 \%$ rata-rata $198,26 \%$ (Yunus, 2007). Konsumsi air minum pada penelitian ini berada pada kondisi normal. 
Tabel 4. Pengaruh penggunaan ekstrak metanol bawang putih sebagai feed additive terhadap konsumsi air minum (The effect of garlic (Allium sativum) methanol extract as feed additive on drinking water consumtion)

\begin{tabular}{lc}
\hline Perlakuan & Rataan (ml/ekor/hari) \\
\hline P0 & $145,09 \pm 13,86$ \\
P1 & $145,13 \pm 6,08$ \\
P2 & $156,76 \pm 13,09$ \\
P3 & $146,85 \pm 19,00$ \\
P4 & $155,12 \pm 4,23$ \\
\hline
\end{tabular}

Keterangan: $\mathrm{P} 0=$ Air minum tanpa penambahan ekstrak metanol bawang putih (kontrol) (drinking water without addition garlic methanol extract 0 ppm (control)); $\mathrm{P} 1=$ Air minum dengan penambahan ekstrak metanol bawang putih $250 \mathrm{ppm}$ (drinking water withaddition garlic methanol extract 250 ppm); P2 = Air minum dengan penambahan ekstrak metanol bawang putih $500 \mathrm{ppm}$ (drinking waterwith addition garlic methanol extract 500 ppm); $\mathrm{P} 3=$ Air minum dengan penambahan ekstrak metanol bawang putih $750 \mathrm{ppm}$ (drinking water with addition garlic methanol extract $750 \mathrm{ppm}$ ); P4 = Air minum dengan penambahan ekstrak metanol bawang putih 1000 ppm (drinking water without addition garlic methanol extract 1000 ppm)

Penggunaan ekstrak metanol bawang putih pada penelitian ini tidak menimbulkan pengaruh negatif terhadap konsumsi air minum ayam broiler yang mengakibatkan ternak membatasi konsumsi air minum secara tidak normal. Menurut Wahju (1992) faktor yang mempengaruhi konsumsi air minum pada ternak antara lain tingkat garam natrium dan kalium dalam ransum, penyakit, jenis bahan makanan, kelembaban dan suhu kandang. Semakin tinggi kadar garam natrium dalam pakan maka konsumsi air minum semakin meningkat pula, begitu juga semakin tinggi suhu di dalam kandang maka suhu tubuh ayam broiler akan meningkat. Peningkatan suhu tuguh inilah yang mengakibatkan proses evaporasi semakin meningkat dengan tujuan panas dalam tubuh akan keluar melalui penguapan (Piliang dan Djojosoebagio, 2006).

Hasil analisis ragam menunjukkan bahwa perlakuan penggunaan ekstrak metanol bawang putih berpengaruh nyata $(\mathrm{P}<0,05)$ terhadap konsumsi ransum (Tabel 5). Dari uji Duncan konsumsi ransum pada ayam broiler periode starter dan periode finisher yang mendapat perlakuan penggunaan ekstrak metanol bawang putih dalam air minum pada taraf 0 ppm (P0) berbeda nyata $(\mathrm{P}<0,05)$ lebih rendah dibandingkan dengan perlakuan 500 ppm (P2), 750 ppm (P3) dan 1000 ppm (P4). Terlihat bahwa penggunaan ekstrak metanol bawang putih sebagai feed additive menyebabkan terjadinya peningkatan konsumsi ransum ayam broiler periode starter maupun periode finisher. Efek penggunaan ekstrak metanol bawang putih terlihat cukup positif merangsang selera makan ayam broiler pada periode starter maupun periode finisher tercermin dengan terjadinya peningkatan konsumsi ransum. Peningkatan konsumsi ransum pada ayam broiler periode starter maupun periode finisher sejalan dengan peningkatan taraf pemberian ekstrak metanol bawang putih, keadaan ini terbukti adaanya peranan senyawa aktif yang terdapat dalam ekstrak metanol bawang putih seperti allicin, ajoene, diakilpolysulphides, s-allylcysteine, diallydisulphide, s-methyl-cysteine, sulphoxide dan s-allylcysteine sulphoxides yang bertanggung jawab membantu sekresi endogen enzyme pencernaan dan konstituen darah sehingga dengan pemberian ekstrak metanol bawang putih dalam air minum ayam dapat mempengaruhi selera makan. Pernyataan ini didukung dengan pendapat Canogullari et al. (2010) mengatakan bahwa suplemen bawang putih (Allium sativum) dapat meningkatkan aktivitas enzim pancreas, 
Tabel 5. Pengaruh penggunaan ekstrak metanol bawang putih sebagai feed additive terhadap konsumsi ransum (The effect of garlic (Allium sativum) methanol extract as feed additive on feed intake)

\begin{tabular}{|c|c|c|}
\hline $\begin{array}{l}\text { Perlakuan }(\%) \\
\text { (Treatments) }(\%)\end{array}$ & $\begin{array}{l}\text { Periode Starter (gr/ekor) } \\
\text { (Starter period ) (g/bird) }\end{array}$ & $\begin{array}{l}\text { Periode Finisher (gr/ekor) } \\
\text { (Finisher period) (g/bird) }\end{array}$ \\
\hline R0 (0 ppm) & $507,37 \pm 10,03^{\mathrm{c}}$ & $615,38 \pm 6,39^{\mathrm{a}}$ \\
\hline R1 (250 ppm) & $568,03 \pm 17,90^{\mathrm{c}}$ & $606,73 \pm 8,11^{\mathrm{a}}$ \\
\hline R2 (500 ppm) & $732,12 \pm 13,01^{b c}$ & $605,55 \pm 4,55^{\text {ba }}$ \\
\hline R3 (750 ppm) & $783,75 \pm 51,70^{\text {ba }}$ & $608,34 \pm 28,93^{\mathrm{bc}}$ \\
\hline R4 (1000 ppm) & $893,72 \pm 2,36^{\text {ba }}$ & $618,57 \pm 17,55^{\mathrm{bc}}$ \\
\hline
\end{tabular}

Keterangan: $\mathrm{P} 0=$ Air minum tanpa penambahan ekstrak metanol bawang putih (kontrol) (drinking water without addition garlic methanol extract 0 ppm (control) ); $\mathrm{P} 1=$ Air minum dengan penambahan ekstrak metanol bawang putih $250 \mathrm{ppm}$ (drinking water with addition garlic methanol extract 250 ppm ); P2 = Air minum dengan penambahan ekstrak metanol bawang putih 500 ppm (drinking water with addition garlic methanol extract 500 ppm); P3 = Air minum dengan penambahan ekstrak metanol bawang putih $750 \mathrm{ppm}$ (drinking water with addition garlic methanol extract 750 ppm); P4 = Air minum dengan penambahan ekstrak metanol bawang putih 1000 ppm (drinking water without addition garlic methanol extract 1000 ppm).

sehingga pencernaan bahan pakan lebih baik dan sekaligus dapat meningkatkan penyerapan zat-zat makanan dalam saluran pencernaan.

Ramakrishna et al. (2003) mengatakan bahwa suplemen bawang putih dapat meningkatkan aktivitas enzim pancreas yang mampu menghidrolisis bahan pakan sehingga enzim tersebut berperan penting dalam pencernaan dan penyerapan zat-zat nutrien dalam tubuh sehingga penyerapan nutrisi lebih baik. Hal ini sejalan dengan hasil penelitian Mansoub (2011), menyatakan bahwa penggunaan tepung bawang putih dalam ransum menyebabkan terjadinya peningkatan konsumsi ransum, berat badan dan menurunkan konversi ransum. Selain itu Pourali et al. (2010) melaporkan bahwa pemberian tepung bawang putih dalam ransum dapat meningkatkan konsumsi harian, konversi ransum serta meningkatkan daya tahan tubuh ayam broiler. Javandel et al. (2008) menyatakan konsumsi ransum ayam broiler fase starter akan lebih tinggi 0,25\% dari pada fase grower bila diberi ransum mengandung tepung bawang putih.

Hasil pengukuran penggunaan ekstrak metanol bawang putih sebagai feed additive terhadap kualitas karkas (bobot potong, bobot karkas, persentase bobot karkas, kolesterol karkas dan bobot lemak abdomen) dapat dilihat pada Tabel 6. Hasil analisis ragam menunjukkan bahwa perlakuan penggunaan ekstrak metanol bawang putih berpengaruh nyata $(\mathrm{P}<0,05)$ terhadap kualitas karkas (bobot potong, bobot karkas, persentase bobot karkas, kolesterol karkas dan bobot lemak abdomen.

Hasil penelitian menunjukkan bahwa perlakuanpenggunaan ekstrakmetanolbawang putih sebagai feed additive berpengaruh nyata $(\mathrm{P}<0,05)$ terhadap bobot potong dan bobot karkas, dan tidak berpengaruh nyata $(\mathrm{P}>0,05)$ terhadap persentase karkas. Ayam broiler yang mendapat perlakuan pembemberian ekstrak metanol bawang putih menghasilkan bobot potong yang nyata $(\mathrm{P}<0,05)$ lebih tinggi dperlakuan dibandingkan dengan ayam yang tanpa pemberian ekstrak metanol bawang putih. Terlihat semakin tinggi taraf penggunaan ekstrak metanol bawang putih sebagai feed additive menghasilkan bobot potong yang tinggi pula. Hasil ini sejalan dengan pola konsumsi ransum yang juga semakin meningkat dengan peningkatan taraf pemberian ekstrak metanol bawang putih. Keadaan ini didukung dengan penyataan Aji et 
al. (2011) pemberian $100 \mathrm{mg}$ tepung bawang putih dalam ransum dapat mengningkatkan pertambahan bobot badan ayam broiler umur 21 hari. Selanjutnya Kumar et al. (2010) melaporkan ransum yang disuplaimentasi bawang putih sebanyak $250 \mathrm{ppm}$ nyata meningkatkan bobot badan ayam broiler. Pourali et al. (2010) mengatakan pemberian tepung bawang putih dalam ransum dapat meningkatkan konsumsi ransum harian, partambahan berat badan, menurunkan konversi ransum serta meningkatkan daya tahan tubuh ayam broiler. Javed et al. (2009) menyatakan bahwa konsumsi pakan, konversi ransum dan bobot badan ayam broiler dapat meningkat diberi ekstrak tanaman obat yang mengandung bawang putih taraf $10 \mathrm{ml} /$ liter dalam air minum. Hal ini diduga senyawa aktif yang terdapat dalam ekstrak bawang putih dapat merangsang ekskresi enzim-enzim pencernaan, sehingga proses pencernaan dalam saluran pencernaan lebih optimal atau lebih baik dan penyerapan zat-zat makanan pun lebih baik atau lebih optimal, sehingga nutrisi yang digunakan untuk pembentukan daging lebih banyak sehingga bobot potong menjadi lebih tinngi pula. Keadaan ini diduga senyawa aktif yang terdapat dalam ekstrak metanol bawang putih mempunyai kemampuan untuk melindungi mikrivili yang bertanggung jawab pada penyerapan zat-zat makanan di dalam usus halus ayam broiler, sehingga daya cerna zat-zat makanan lebih baik dan penyerapan zat-zat makananpun menjadi lebih sempurna, akibatnya retensi zat-zat makananpun menjadi lebih tuinggi terutama retensi protein yang berdampak terhadap pembentukan bobot badan. Corzo et al. (2005) mengatakan senyawa aktif fenolik mempunyai kemampuan untuk melindungi vili-vili usus dan bertanggung jawab pada penyerapan zat-zat makanan di dalam usus halus ayam. Bawang putih mengandung 33 senyawa aktif yang mengandung sulfur, beberapa enzim, 17 asam amino dan mineral termasuk selenium (Newall et al., 1996). Selanjutnya Ramakrishna et al. (2003) mengatakan bahwa suplemen bawang putih dapat meningkatkan aktivitas enzim pankreas dan menyebabkan penyerapan nutrisi makin lebih baik.

Ayam broiler yang mendapat perlakuan pemberian ekstrak metanol bawang putih cenderung memperlihatkan bobot karkas yang lebih tinggi dibandingkan dengan perlakuan tanpa pemberian ekstrak metanol bawang putih. Hasil bobot karkas ini sejalan dengan pola konsumsi ransum. Hal ini menunjukkan bahwa bobot karkas yang dihasilkan proporsional dengan bobot potong dan bobot karkas mengikuti bobot potong. Keadaan ini diduga senyawa aktif yang terdapat dalam ekstrak metanol bawang putih dapat berfiungsi sebagai growth promoter. Senyawa aktif yang terdapat dalam bawang putih antara lain: allicin, ajoene, diakil polysulphides, s-allylcysteine, diallydisulphide, s-methylcysteine sulphoxide dan s-allylcysteine sulphoxide, dimana senyawa aktif ini akan bertanggung jawab atas sifat terapeutik Canogullari et al. (2010). Dugaan lain mungkin disebabkan peran senyawa aktif dalam ekstrak metanol bawang putih sebagai antibakteri sehingga senyawa-senyawa aktif yang terdapat pada ekstrak metanol bawang putih dapat mengurangi jumlah populasi bakteri patogen pada saluran pencernaan ayam dan dapat meningkatkan bakteri asam laktat, sehingga dapat meningkatkan aktivitas enzyme pencernaan dan meningkatkan kecernaan nutrisi dan memperbaiki, mengatur dan menstabilkan mikroba usus dan menyebabkan penyerapan zat-zat nutrisi lebih sempurna akibatnya berpengaruh terhadap bobot potong yang dihasilkan. Vadanarachchi et al. (2006) melaporkan bahwa senyawa aktif yang terdapat dalam tumbuh-tumbuhan termasuk bawang putih berfungsi sebagai antibakteri sehingga dapat mengurangi jumlah populasi bakteri patogen dan dapat meningkatkan jumlah bakteri non patogen.

Hasil penelitian menunjukkan bahwa perlakuan pemberian ekstrak metanol bawang putih tidak nyata berpengaruh $(\mathrm{P}>0,05)$ terhadap persentase karkas (Tabel 6). Ayam broiler yang diberi ekstrak metanol bawang 
Tabel 6. Pengaruh penggunaan ekstrak metanol bawang putih sebagai feed additive terhadap bobot potong, bobot karkas, persentase karkas, kolesterol karkas dan lemak abdomen ayam broiler (The effect ofgarlic methanol extract as feed additive on slaughter weight, carcass weight, carcass percentage, carcass cholesterol and fat abdominal broiler chicks)

\begin{tabular}{lccccc}
\hline \multirow{2}{*}{ Peubah (Variabel) } & \multicolumn{5}{c}{ Perlakuan (Treatments) } \\
\cline { 2 - 6 } & $\mathrm{P} 0$ & $\mathrm{P} 1$ & $\mathrm{P} 2$ & $\mathrm{P} 3$ & $\mathrm{P} 4$ \\
\hline Bobot Potong (gr) & $1098,24 \pm$ & $1122,39 \pm$ & $1169,09 \pm$ & $1190,10 \pm$ & $1230 \pm$ \\
(Slaughter weight) $(g)$ & $35,05^{\mathrm{d}}$ & $34,51^{\mathrm{dc}}$ & $72,78^{\mathrm{dcb}}$ & $19,04^{\mathrm{cb}}$ & $58,72^{\mathrm{b}}$ \\
Bobot karkas $(\mathrm{gr})$ & $674,12 \pm$ & $680,62 \pm$ & $698,62 \pm$ & $746,50 \pm$ & $809,87 \pm$ \\
(carcass weight) $(g)$ & $15,90^{\mathrm{ba}}$ & $53,49^{\mathrm{ba}}$ & $06,01^{\mathrm{ba}}$ & $72,23^{\mathrm{b}}$ & $37,38^{\mathrm{ba}}$ \\
Persentase karkas & $64,75 \pm$ & $63,06 \pm$ & $68,91 \pm$ & $69,82 \pm$ & $66,33 \pm$ \\
(Carcass percentage)(\%) & $2,19^{\mathrm{b}}$ & $0,84^{\mathrm{b}}$ & $0,80^{\mathrm{b}}$ & $2,93^{\mathrm{b}}$ & $1,91^{\mathrm{b}}$ \\
Kolesterol karkas (mg/100g) & $142,62 \pm$ & $122,62 \pm$ & $103,17 \pm$ & $99,46 \pm$ & $94,46 \pm$ \\
(Carcass cholesterol) & $4,09^{\mathrm{a}}$ & $24,80^{\mathrm{b}}$ & $0,15^{\mathrm{cb}}$ & $51,4^{\mathrm{cb}}$ & $15,04^{\mathrm{cb}}$ \\
(mg/100g) & & & & & \\
Lemak Abdomen (\%) & $5,37 \pm 0,21^{\mathrm{a}}$ & $5,19 \pm 0,90^{\mathrm{a}}$ & $3,87 \pm 0,18^{\mathrm{a}}$ & $3,04 \pm 0,9^{\mathrm{a}}$ & $3,75 \pm 0,13^{\mathrm{a}}$ \\
(Fat abdominal) (\%) & & & & &
\end{tabular}

Keterangan: $\mathrm{P} 0=$ Air minum tanpa penambahan ekstrak metanol bawang putih (kontrol) (drinking water without addition garlic methanol extract 0 ppm (control) ); P1 = Air minum dengan penambahan ekstrak metanol bawang putih $250 \mathrm{ppm}$ (drinking water withaddition garlic methanol extract $250 \mathrm{ppm}$ ); $\mathrm{P} 2$ = Air minum dengan penambahan ekstrak metanol bawang putih $500 \mathrm{ppm}$ (drinking water with addition garlic methanol extract 500 ppm); P3 = Air minum dengan penambahan ekstrak metanol bawang putih $750 \mathrm{ppm}$ (drinking water with additiongarlic methanol extract 750 ppm); P4 = Air minum dengan penambahan ekstrak metanol bawang putih 1000 ppm (drinking water with addition garlic methanol extract 1000 ppm)

putih pada taraf $1000 \mathrm{ppm}(\mathrm{P} 4)$ dan $750 \mathrm{ppm}$ (P3) cenderung memperlihatkan persentase karkas yang lebih tinggi dibandingkan perlakuan dengan tanpa penambahan ekstrak metanol bawang putih (P0). Namun demikian secara keseluruhan perlakuan belum memperlihatkan efek yang nyata $(\mathrm{P}>0,05)$ terhadap persentase karkas. Hal ini menunjukkan bahwa persentase karkas yang dihasilkan proposional dengan bobot badan akhir. Bobot karkas mengikuti bobot badan akhir, persentase karkas pada penelitian ini berkisar antara $63,06 \pm 0,84 \%$ yang terendah sampai $68,91 \pm 0,80 \%$ yang tertinggi. Persentase karkas ini merupakan perbandingan bobot karkas dengan bobot akhir ayam broiler, sehingga bila bobot akhir yang besar diikuti dengan bobot karkas yang besar pula dan begitu sebaliknya. Hasil penelitian ini lebih tinggi dari Nadeem et al. (2005) yaitu 59,76-61,97\%. Hal ini berarti bahwa pemberian ekstrak metanol bawang putih dapat dilakukan tanpa menyebabkan penurunan persentase karkas. Mahmood et al. (2009) mengatakan pemberian ransum basal pada ayam broiler yang mengandung tepung bawang putih taraf $0,5 \%$ dapat meningkatkan konversi ransum, bobot badan meskipun persentase karkas tidak meningkat. Javed et al. (2009) melaporkan bahwa pemberian ekstrak tanaman obat yang mengandung bawang putih $10 \mathrm{ml} /$ liter air minum ayam broiler dapat meningkatkan konsumsi ransum, bobot badan, konversi ransum serta kualitas karkas tetapi tidak berpengaruh dengan persentase karkas. Ramakrishna et al. (2003) menyarankan bahwa suplemen bawang putih meningkatkan aktivitas enzim pankreas dan menyediakan 
lingkungan untuk penyerapan nutrisi yang lebih baik. Javandel et al. (2008) mengatakan bahwa pemberian ransum yang mengandung tepung bawang putih pada taraf 0,125 dan $0,25 \%$ pada ayam broiler menghasilkan konsumsi ransum yang lebih tinggi selama fase starter, meskipun persentase karkas, usus kecil, proventrikulus, gizard tidak nyata.

Hasil pengukuran pemberian ekstrak metanol bawang putih sebagai feed additive dalam air minum terhadap kandungan kolesterol karkas tercantum pada Tabel 6 . Hasil analisis ragam menunjukkan bahwa perlakuan pemberian ekstrak metanol bawang putih nyata berpengaruh $(\mathrm{P}<0,05)$ terhadap kadar kolesterol karkas. Dari uji Duncan kadar kolesterol karkas pada ayam broiler yang mendapat perlakuan tanpa pemberian ekstrak metanol bawang putih (P0) lebih rendah dibandingkan dengan perlakuan pemberian ekstrak metanol bawang putih. Efek pemberian ekstrak metanol bawang putih terlihat cukup positif $(\mathrm{P}<0,05)$ menurunkan kadar kolesterol karkas ayam broiler. Keadaan ini diduga peran senyawa aktif bawang putih seperti allicin, ajoene, diakil polysulphides, s-allylcysteine, diallydisulphide, s-methylcysteine sulphoxide dan s-allylcysteine sulphoxide bekerja menghambat sintesa apolipoprotein $\mathrm{B}$ dan trigliserida yang merupakan komponen utama protein LDL, sehingga kandungan kolesterol karkas menjadi rendah (Borradaile et al., 1999). Disamping itu juga adanya peran senyawa aktif merupakan bahan antioksidan yang mampu menetralkan oksigen reaktif dan berkontribusi terhadap penurunan kadar kolestrol darah. Keadaan ini diduga peran senyawa aktif yang terdapat dalam ekstrak metanol bawang putih dapat mengurangi kandungan apolipoprotein $B$ yang merupakan komponen utama protein dari LDL akibatnya kadar kolesterol menjadi turun. Hal ini sesuai dengan pendapat Yang et al. (2011) mengatakan senyawa aktif yang terdapat pada tanaman dapat meningkatkan enzim antioksidan dalam sel darah merah, sehingga dapat menurunkan kadar kolesterol darah. Keadaan ini sejalan dengan pendapat
Canogullari et al. (2010) pemberian ransum yangmengandung tepung bawang putih sampai taraf $2 \%$ dalam ransum ayam petelur nyata menurunkan kadar kolesterol telur. Ahsanul-Haq et al. (1999) mengatakan pemberian tepung bawang putih sebanyak $20 \mathrm{~g} / \mathrm{kg}$ dalam ransum dapat menurunkan kadar kolesterol darah ayam broiler. Chowdhury et al. (2002) melaporkan bahwa konsentrasi kolesterol per gram kuning telur menurun secara linier dengan meningkatnya kadar tepung bawang putih dalam ransum ayam petelur. Khan et al. (2007) menyatakan ransum ayam petelur yang mengandung tepung bawang putih sampai $8 \%$ nyata menurunkan kadarkolesterol kuning telur. Lebih lanjut Khan et al. (2008) melaporkan ransum ayam petelur yang diberi tepung bawang putih sampai taraf $8 \%$ menghasilkan kolesterol serum dan kolesterol telur yang lebih rendah. Canogullari et al. (2010) pemberian tepung bawang putih sampai taraf $4 \%$ dalam ransum ayam broiler nyata menurunkan konsentrasi lipid total dan kadar trigliserida total. Tingkat trigliserida total dapat diturunkan dengan suplementasi bubuk bawang putih hingga taraf $2 \%$ bawang putih dalam ransum ayam petelur (Azeke and Ekpo, 2008). Yalcin et al. (2006): Youn et al. (1996) melaporkan bahwa kadar trigliserida darah nyata dapat diturunkandengan suplementasi tepung bawang putih dalam ransum. Rehman et al. (2011) melaporkan bahwa campuran ransum yang mengandung bawang putih dapat menurunkan kolesterol darah.

Hasil analisis ragam menunjukkan bahwa perlakuan pemberian ekstrak metanol bawang putih nyata berpengaruh $(\mathrm{P}<0,05)$ terhadap lemak abdomen ayam broiler (Tabel 6). Dari uji Duncan ayam broiler yang diberi ekstrak metanol bawang putih memperlihatkan kandungan lemak abdomen cenderung sama. Namun pengaruh perlakuan tanpa pemberian ekstrak metanol bawang putih lebih tinggi dibandingkan dengan perlakuan pemberian ekstrak metanol bawang putih. Hal ini menunjukkan bahwa peningkatan pemberian ekstrak metanol bawang putih pada ayam 
broiler berdampak positif terhadap penurunan kandungan lemak abdomen ayam broiler. Terlihat bahwa semakin tinggi taraf pemberian ekstrak metanol bawang putih dalam air minum maka makin rendah kandungan lemak abdomen ayam broiler. Hasil ini sejalan dengan pola kolesterol karkas yang juga semakin menurun dengan peningkatan taraf pemberian ekstrak metanol bawang putih dalam air minum. Dari hasil penelitian ini membuktikan bahwa ekstrak metanol bawang putih dapat digunakan sebagai antioksidan yang dapat menurunkkan lemak abdomen ayam broiler. Komponen aktif utama dalam bawang putih adalah allicin, ajoene, diakil polysulphides, s-allylcysteine, diallydisulphide, s-methylcysteine sulphoxide dan s-allylcysteine sulphoxide, yang akan bertanggung jawab atas sifat terapeutik Canogullari et al. (2010). Lebih lanjut dikatakan komponen aktif allicin merupakan komponen aktif alami penting dan dominan yang terdapat dalam bawang putih dan dapat mengurangi lemak darah dan lemak abdomen.

Selain itu juga senyawa aktif dalam bawang putih bertanggung jawab untuk meningkatkan kesehatan dan bermanfaat sebgai hypocholesterolaernic, karena dapat mengurangi sintesis kolesterol, serta menghambat sintesis asam lemak dan agregasi trombosit dan mencegah trombosis (Canogullari et al., 2010). Disamping itu juga allicin adalah senyawa organik yang mudah menguap yang telah terbukti mengurangi lipid serum, fosfolipid dan kolesterol total dan menekan sintesis kolesterol pada ayam Horton et al. (1991).

\section{KESIMPULAN}

Berdasarkan hasil penelitian dapat diambil kesimpulan pemberian ekstrak metanol bawang putih (Allium sativum) sampai taraf $1000 \mathrm{ppm}$ dalam air minum sebagai feed additive memberi respon positif terhadap kualitas karkas dan konsumsi ransum ayam broiler.

\section{DAFTAR PUSTAKA}

Adibmoradi, M., B. Navidshad, J. Seifdavati, and M. Royan. 2006. Effec of dietary garlic meal on histological structure of small intestine in broiler chickens. J. Poult Sci. 43: 378-383.

Ahsan. U. H., K. A. Meraj. and S. Rasool. 1999. Effec of supplementing Allium sativum and Azidirachta indica leaves in broiler feeds on their blood cholesterol, triglycerides and antibody titre. J. Agric and Bio 1: 125-127.

Aji, S. B., K. Ignatius, A. Y. Ado, J. B. Nuhu., and A. Abdulkarim. 2011. Effect of feeding onion (Allium cepa) and garlic (Allium sativa) on some performance characteristic of broiler chickens. J. Poult Sci 4: 22-27.

Azeke, M. A, and K. E. Ekpo. 2008. Egg yolk cholesterol lowering effects of garlic and tea. J. Biol Sci 8: 456-460.

Borradaile. N. M., K. K. Carrol, E. M. Kurowsha. 1999. Regulation of HepG2 cell apolipoprotein B metabolism by the citrus flavonones hesperetion and naringerin lipids. 34: 591-598.

Canogullari, S., M. Baylan, Z. Erdogan, V. Duzguner, and A. Kucukgue. 2010. The effects of dietary garlic powder on performance, egg yolk and serum cholesterol concentrations in laying quails. J. Anim Sci 55: 286-293.

Chowdhury, S. R., S. D. C howdhury, and T. K. Smith. 2002. Effect of dietary garlic 0n cholesterol metabolism in laying hens. J. Poult Sci 81: 1856-1862.

Corzo. A., C. A. Fritts, M. T. Kidd, and B. J. Kerr. 2005. Response of broiler chicks to essential and non essential amino acid supplementation of low crude protein diets.J. Anim. Sci and Tech. 118: 319-327.

Dorhoi, A., V. Dobrean, M. Zahan, and P. Virog. 2006. Modulatory effects of several herbal extracts on avian 
peripheral blood cell immune responses. J. Phytotherapy $20: 352-358$.

Hanieh, H., K. Narabara, M. Piao, C. Gerile, A. Abe, and Y. Kondo. 2010. Modulatory effects of two levels of dietary Allium on immune response and certain immunological variables, following immunization in white leghorn chicken. J. Phytotherapy $20: 352-358$.

Herman, M. 2005. Pengaruh pemberian larutan rimpang kunyit dalam air minum terhadap pertambahan bobot badan ayam broiler. Skripsi Fakultas Peternakan Universitas Jambi, Jambi.

Horton, G. M. J., M. J. Fenneli, and B. M. Prasad. 1991. Effects of dietary garlic (Allium sativum) on performance, carcass composition and blood chemistry changes in broiler chickens. J. Anim Sci 71: 939-942.

Javandel, F., B. Navidshad, J. Seifdavati, G. H. Pourrahimi, and S. Baniyaghoub. 2008. The favorite dosage of garlic meal as a feed additive in broiler chickens ration. J. Bio Sci 11: 1746-1749.

Javed, M., F. Durrani, A. Hafeez, R. U. Khan, and I. Ahmad. 2009. Effect of agneous extract of plant mixture on carcass quality of broiler chicks. J. Agric Bio Sci 4: 37-40.

Khan, R.U., S. Naz, V.Tufarelli, M. Selvaggi, and V. Laudadio. 2011. The use of turmeric (Curcuma longa) in poultry feed. J.Poult Sci 68:97-103.

Khan, Q. S. H., S. Hasan, R. Sardar, and M. A. Anjum. 2008. Effects of dietary garlic powder on cholesterol concentration in native laying hens. J. Food Tech 3 : 207-213.

Khan, R.U., F. R. Durrani, and N. Chand. 2010. Influence of feed supplementation with Cannabis sativa on quality of broilers carcass. J. Vet Sci 30 : 34-38.

Khan, S. H., R. Sardar, and M. A. Anjum. 2007. Effects on dietary garlic on performance and serum and egg yolk cholesterol concentration in laying hens. J. Anim Sci 21: 22-27.

Kumar. S., K. C. Sharadma, and Radha Krishna 2010. Effect of a garlic active based growth promoter on growth performance and specific pathogenic intestinal microbial counts of broiler chicks. J. Poult Sci. 9 : 244-246.

Mahmood, S., M. M. Hassan, M. Alam, and F. Ahmad.2009. Comparative efficacy of Nigella sativa and Allium sativumas growth promoters in broilers. J. Agric Bio 11: 775-778.

Manesh, M. K. 2012. Influence of poly germander (Teucrium polium) and watercress (Nasturtium officinale) extract on performance, carcass quality and blood metabolites of male broilers. J. Anim Vet Sci 30: 34-38.

Mansoub, N. H. 2011. Comparative effects of using galic as probiotic on performance and serum composition of broiler chickens. J. Anim Bio Sci 2: 486-490.

NRC. 1994. Nutrient requirements of poultry. Ninth revised edition National Academy press Washington DC.

Nadeem, M. A., M. I. Anjum, A. G. Khan, A. Azim. 2005. Effect of dietary supplementation of non- starch polysacharida degrading enzyme on growth performance of broiler chicks. J. Vet Sci 25: 183-188.

Newall. C. A., L. A. Anderson, and J. D. Phillipson. 1996. Herbal medicine a guide for health - core professionals. Pharmaceutical press. London.

Nurhayati. 2008. Pengaruh pemberian jus buah mengkudu (Morinda citripolia) dalam air minum terhadap penampilan ayam broiler jantan. J. Agripet 8:(1): 39-44.

Perez, J. L., G. K. Jayaprahasha., A. Cadena., E. Martinez., H. Ahmad, and B. S. Patie. 2010. In vivo induction of phase II detoxifying enzymes glutathione transferase and quinine reductase by 
citrus triterpenoids. Complementary and Alternative Medicine 10: 51. http://www.biomedcentral.com14726882/10/51

Pourali, M., S. A. Mirghelenj, and D. Kermanshaki. 2010. Effect of garlic powder on productive performance and immune response of broiler chickens challenged with Newcastle disease virus. J. Vet Sci 4: 616-621.

Rahimi, S., T. Zadeh, M. A.Karimi, R. Omidbaigi, and H. Rokni. 2011. Effect of the three herbal extracts on growth performace. Immune system, blood factors, and intestinal selected bacterial population in broiler chickens. J. Agric Sci Tech13: 527-539.

Rahmatnejad, E., O. Roshanfekr, M. Asharyerizadeh, Mammooee and A. Ashayerizadeh. 2009. Evaluation of several non-antibiotic additives on growth performance of broiler chickens. J. Anim Vet Sci 8: 1670-1673.

Ramakrisnha, R. R., K. Platel, and K. Srinivasan. 2003. In vitro influence of species and spice active principle on digestive enzyme of rat pancreas and small intestine. J. Nahrung 47 : 408412.

Rehman, S., F. R. Darrani, N. Chand, R. U. Khan, and F. Remahn. 2011. Comparative efficacy of different schedules of administration of medicinal plants infusion on hematology and serum biochemistry of broiler chicks. J. Anim Vet Sci1 : 8-14.

Sojoudi, M. R., M. Dadashbeiki, and M. Bouyeh. 2012. Effects of different levels of symbiotic, Technomos on broilers performance. J. Anim and Vet Sci 2: 243-248.

Wahju. 1992. Ilmu Makanan Ternak. Jogjakarta: Universitas Gajah Mada Press.

Yalcin, S., E. E. Onbasilar, Z. Reisli, and S. Yalcin. 2006. Effect of garlic powder on the performance, egg traits and blood parameters of alying hens. J. Food Agric Sci 86: 1336-1339.

Yang. X. Y., J. X. Xie., F. F. Wang., J. Zhong., Y. Z. Liu., G. H. Li, and S. A. Peng. 2011. Comparison of ascorbate metabolism in fruits of two citrus species with obvious difference in ascorbate content in pulp. J. Plant Physiol 168: 2196-2205.

Youn, B. S., K. T. Nam, C. W. Kim, C. W. Kang, S. Ohtani, and K. Tanaka. 1996. Effects of dietary garlic suplementation on performance and HMG-CoA reductase in broiler chicks. J. Poult Sci 23: 129-134.

Yunus, S. T. 2007. Pengaruh level pemberian air kunyit melalui air minum terhadap bobot karkas, giblet, dan lemak abdominal broiler. Skripsi Fakultas Peternakan Universitas Lampung. Lampung. 